in the last three years. During the past year the boulder has been at a part of the glacier which is steeper than where it was previously. This may explain the slightly accelerated movement during the last year. I do not rely implicitly on the 44 days' observation, but if it be assumed to be correct, it leads to the inference that the movement in summer is 2 in. per day, and in winter 1 in.

In the first four years there was no perceptible disturbance of the position of the boulder on the sustaining ice. During the last year it has twisted a little.

Last summer I took some observations to ascertain the superficial waste of the glacier on a part which was free from moraine (during fine sunny weather), and found it amount to about 3 in. per day. This summer I have again taken observations, in a different manner, extending over 21 days; these gave a result of over 2 in. per day.

Forbes states that the waste is as much as 3 in. a day in a hot summer. Now on comparing the scale of movement with that of the waste by melting, I get results which I cannot reconcile.

The boulder which I have had under observation cannot have come from any mountain which is less than three miles distant from its present position. The angle of the glacier above the part where it rests, is less, rather than greater. I therefore assume that the recorded rate of movement may be taken as an average, in which case the boulder must have been travelling 400 years.

The depth of the glacier is probably not more than 300 feet, but I will assume it to be 600 feet, and that the average waste is only two inches a day, during three summer months, or fifteen feet per annum. On this assumption the whole depth of 600 feet would be melted in forty years. I have taken observations of the relative movement of the glacier, where covered with moraine, and also where free from it. They do not encourage the supposition that there is any material difference.

F. LLOYD.

19 th August, 1880.

\title{
THE PERMANENCE OF OCEANS AND CONTINENTS.
}

Sin,-Mr. T. M. Reade, in your September Number, quotes certain authors who believe that oceans and continents have, throughout all known geological time, occupied pretty much the same relative positions as now.

There is, however, one important omission in this list. In the famous chapter in the Origin of Species, "On the Imperfection of the Geological Record," Mr. Darwin endeavours to account for the sudden appearance of groups of allied species in the lowest known fossiliferous strata; he does this by assuming that the Pre-Silurian continents probably existed where the oceans now are. He says : "We may infer that where our oceans now extend, oceans have extended from the remotest period of which we have any record; and on the other hand, that where continents now exist, large tracts of land have existed, subjected no doubt to great oscillations of level, since the earliest Silurian period. ...... At a period immeasurably antecedent to the Silurian epoch, continents may have 
existed where oceans are now spread out; and clear and open oceans may have existed where our continents now stand." (Quoted from 3rd ed. 1861, p. 335; 1st ed. published in 1859.)

This and similar statements in the same chapter were then regarded as pure assumptions on Mr. Darwin's part, made to evade a difficulty which the author himself admitted "may be truly urged as a valid argument against the views here entertained." The inference in the first half of the quotation given above will probably now be accepted by most geologists; that in the second half may not yet gain so general a belief. The "Record" of Palæozoic life has been carried far back since the publication of the "Origin of Species," but the difficulty remains much as it did, and can probably only be explained in the manner stated by Mr. Darwin.

Geological Survey Orfice, London, September $25 t h, 1880$.

W. Toplex.

\section{POST-GLACIAL.}

SiR,-In a letter in your last Number under the above beading, Mr. Dalton referred to the mention of a burnt stone, or what appeared like one, found by me at Lexden brickpit, and argues from it that Palæolithic Man, the contemporary of these great beasts, was, as man is now, a "cooking animal." But this burnt stone, if such it was, was not found in the same stratum with the pachyderms, but in brick-earth overlying it. I believe I made this sufficiently clear in my paper upon the deposit (Quart. Journ. Geol. Soc. 1863, p. 396).

I am rather disposed to think that this brick-earth is considerably more recent than the peat, in and beneath which the bones of elephants and rhinoceroses were so abundant.

O. Fisher.

Harlton, Cambridge, 6 Nov.

\section{"FOSSILS OTHERWISE THAN ON BEDDING PLANES."}

Sin,--Since the appearance of my letter in your September Number, I have been confirmed in my view by several other observers, and I would especially mention two who have kindly furnished me with definite instances in point. Mr. Ussher lately sent me a specimen from the Lower Lias near Newark, showing Ammonites planorbis occurring nearly vertically to the bedding; and by this morning's post (Oct. 26th) I have received from the same locality, through the kindness of Mr. Dalton, a drawing of two specimens of Ammonites semicostatus traversing the bedding, the one at an angle of about $45^{\circ}$, the other at an angle of about $30^{\circ}$.

I have already suggested what appear to me certain vera cause for the occurrence of fossils in such positions. I will only now add that if conditions should hereafter supervene which should alter the character of these Liassic beds, obliterating the bedding and superinducing cleavage, rendering them in fact mineralogically similar to the Silurian slates before referred to, the only fossils visible in them would as a rule be those which happened to coincide with the cleavage planes.

W. Downes,

Kentisbeare, Collumpton, October' $26 t h, 1880$. 